\title{
Discovering Ecological Awareness of Filipino Education Students
}

\author{
Genalyn P. Lualhati ${ }^{1}$, Frances Jane A. Catibog ${ }^{1}$, Rose Anne L. Holgado ${ }^{1} \&$ John Mark A. Liwanag ${ }^{1}$ \\ ${ }^{1}$ College of Teacher Education, Batangas State University JPLPC- Malvar Campus, Batangas Province, \\ Philippines \\ Correspondence: Genalyn P. Lualhati, College of Teacher Education, Batangas State University JPLPC- Malvar \\ Campus, Batangas Province, Philippines. E-mail: genpanganiban_0301@yahoo.com, jane_catibog@yahoo.com, \\ roseanneholgado@gmail.com, brightjm16@gmail.com
}

Received: October 5, 2018; Accepted: October 28, 2018; Published: October 30, 2018

\begin{abstract}
Ecological awareness is a way of thinking about the world in terms of its interdependent natural and human systems, including a consideration of the consequences of human actions and interactions within the natural context. Hence, this research determined the level of ecological awareness of Filipino education students, with the aim of strengthening their ecological awareness through enrichment activities. The input of the study was determined by employing self-made questionnaire as the principal tool for gathering data. Through appropriate statistical tools and analyses of data, the study revealed that the respondents are greatly female individuals who belonged to the bracket of middle income, reached high school level which was the parent's highest educational attainment and acquired General Weighted Average (GWA) in Natural Sciences (NS) ranging from 2.00-2.49. It also revealed that the respondents are aware when it comes to caring and practical competency. Further, it was revealed that there is no significant relationship between sex and ecological awareness while there is a significant relationship between socio-economic status, parent's highest educational attainment, GWA in NS and ecological awareness. The above-mentioned findings recommend to conduct programs that integrate caring, knowledge, and action that determine potential to enhance student's ecological awareness and promote transparency and public participation in decision-making, and access to justice in environmental matters.
\end{abstract}

Keywords: Ecological Awareness, Caring, Practical Competency, Knowledge, Filipino Education Students

\section{Introduction}

Since the turn of the new millennium, the world is facing different environmental issues that may harm people, societies and ecosystems. Environmental issues are the result of harmful human activities on the biophysical environment. Such issues that people are experiencing today are global warming, climate change, pollution and environmental degradation. It can be clearly seen that humans created this problem. Thus, it is a must to promote environmental awareness through environmental education to prevent this phenomenon.

In the light of promoting environmental awareness, the Commission on Higher Education amended the Republic Act No. 9512, otherwise known as the "National Environmental Awareness and Education Act of 2008\| which aims to integrate environmental education in school curricula at all levels, whether public or private, including in barangay daycare, preschool, non-formal, technical vocational, professional level, indigenous learning and out-ofschool youth courses or programs with the help of Department of Education (DepEd), the Commission on Higher Education (CHED), the Technical Education and Skills Development Authority (TESDA), the Department of Social Welfare and Development (DSWD), in coordination with the Department of Environment and Natural Resources (DENR), the Department of Science and Technology (DOST) and other relevant agencies. The said order also involved implementing different environmental laws that would help the human beings to be educated and aware to build a more sustainable world (The LAWPHIL Project, 2008).

Pursuant to the policy set forth in the Act, it is stated that the month of November of every year will be known as the "Environmental Awareness Month" throughout the Philippines. Also, for better training, the CHED and the TESDA include environmental education and awareness programs and activities in the National Service Training Program under Republic Act No. 9163, as part of the Civic Welfare Training Service component which required all baccalaureate degree courses and vocational courses with a curriculum of at least two years.

In line with this problem, awareness and literacy is indeed an important variable. Awareness is a human right, a tool of personal empowerment and a means for social and human development. Educational opportunities depend 
on literacy. It is at the heart of basic education for all and essential for eradicating poverty, reducing child mortality, curbing population growth, achieving gender equality and ensuring sustainable development, peace, and democracy (Nordquist, 2017; UNESCO, 2010)

Literacy is indispensable to raise awareness and gather necessary grass roots participation in efforts to improve the way humans care for the planet and manage its resources. This transformation can only happen if society's most vulnerable youth and adults acquire basic literacy skills that equip them with the knowledge and confidence to improve their own lives and build more resilient communities (UNESCO, 2015). In relation to environmental issues, acquiring literacy in environment and its ecological systems serves an important purpose. The said literacy can be termed as - Ecological Literacy or - Eco-literacy Ecological literacy draws it meaning from multiple time periods and scholars (McGinn, 2014).

In Bruyere's (2008) analysis of definitions of ecological literacy, he identifies that although varied definitions of ecological literacy exist, commonalities run through the literature. The similarities boil down to three components; cognitive, affective, and behavioral which must fuse to make an ecologically literate person (Bruyere, 2008). Each of these three components is emphasized or implied in different definitions. In some definitions knowledge is the primary emphasis while in others people 's actions are weighted higher than people 's knowledge. For the purpose of this study, the areas of ecological literacy are considered of equal importance, and a person must have knowledge. They must feel a connection to the issues, and they must exhibit sustainable behaviors. Knowledge alone is not enough to constitute ecological literacy.

Further, another components of ecological literacy are caring (Affective), knowledge (Cognitive), and practical competency (Behavioral). Caring gauges a person 's level of compassion for environmental protection and social justice. A caring person, in this context, feels a desire to and responsible for reducing their personal and communal impact on ecological systems. This section is reflective of a person's mindset, not actions. Knowledge represents an understanding of ecological principals and humans' interactions with their built and natural environments.

Moreover, according to Cherrett, as cited by Mcginn (2014), a person needs to be aware of his environment, as this is the foundation and starting point of literacy. Nowadays, knowledge is no longer limited to extensive memorization of concepts, but raised awareness is a prerequisite for a successful learning. An ecologically aware person would have an understanding of imperative ecological concepts such as ecosystem succession, energy flow, materials cycling, ecological adaptation, food webs, carrying capacity, and species diversity. Further, they are mindful of actions that they can be taken to build sustainable and health communities.

With the importance of honing ecological aware person prior to producing literate populace that this study had conceptualized. The researchers, who are Science educators, can use the findings of this study to be more effective molders of civic-minded youth, who have good sense of humanity to take good actions towards the environment. Lastly, this may also aid them in becoming more engaged and actively involved in promoting care and action for the environment to entail progress and awareness to the world where everyone lives in.

\section{Objectives of the Study}

This study determined the level of ecological awareness of Filipino education students at BatStateU JPLPC Malvar, with an end view of formulating enrichment activities to strengthen their ecological awareness. Specifically, the study sought the respondents' profile in terms of sex, socio-economic status, parent's highest educational attainment, and General Weighted Average (GWA) in Natural Science. Further, this determined the assessments on the level of ecological awareness in terms of caring and practical competency. Lastly, significant relationship of the profile and their assessed level of ecological awareness was sought.

\section{Materials and Methods}

\subsection{Research Design}

This study used of descriptive method of research. This type of research according to Calmorin as cited by Fababaer et.al (2013), is a scientific method which focuses at the present condition for the purpose of the new truth. It is a research that is valuable in providing facts on which scientific judgment may be based on essential knowledge about the nature of objects and persons for closer observation into the practices behaviors, methods and procedures. In this endeavor, the researchers believed that through descriptive method, they could determine the level of ecological awareness and the profile of Filipino education students at BatStateU JPLPC - Malvar.

\subsection{Subject of the Study}

The respondents of this study are the 111 sophomore education students at BatStateU JPLPC - Malvar who were officially enrolled during the academic year 2016-2017, and who had successfully finished and passed Natural Science courses. 


\subsection{Instrumentation}

In gathering the instrument, the researchers used a researcher-made questionnaire that is composed of two parts. The first part focused on the profile of the respondents in terms of sex, socio-economic status, parent 's highest educational attainment and GWA in Natural Science while the last part dealt with the respondents' level of ecological awareness in terms of caring and practical competency.

\subsection{Data Collection Procedure}

This study started through seeking permission from the concerned authorities to utilize the sophomore education students as respondents. After securing the necessary documents, the researchers asked for the list of the students who were officially enrolled in the department. From the list, the target respondents were determined. The revised copy of the questionnaire was prepared, reproduced and administered to the target respondents. The researchers personally distributed and retrieved the questionnaires. The responses were tallied, tabulated, analyzed and interpreted.

\section{Results and Discussions}

This chapter covers the presentation, analysis and interpretation of the data gathered regarding the study. The data were tabulated accurately and justified to provide an in depth analysis and interpretation. It was also arranged sequentially in a manner that coincides with the organization of the problems posed in the study.

Table 1. Percentage distribution of the respondents' profile

\begin{tabular}{lll}
\hline Profile Variables & Frequency & Percentage \\
\hline Sex & & \\
\hline Male & 20 & 18 \\
Female & 91 & 82 \\
\hline Socio-Economic Status & & \\
\hline High Income (P37,000.00 above) & 6 & 5 \\
Middle Income (P10,000.00- P37,000.00) & 71 & 64 \\
Low Income (P9,999.00 and below) & 34 & 31 \\
\hline \multicolumn{2}{l}{ Parent's Highest Educational Attainment } & \\
\hline Master & 2 & 2 \\
College & 45 & 40 \\
High School & 60 & 54 \\
Elementary & 4 & 4 \\
\hline General Weighted Average (GWA) in Natural Science \\
\hline 1.50-1.99 & 36 & 32 \\
$2.00-2.49$ & 71 & 64 \\
$2.50-3.00$ & 4 & 4 \\
\hline
\end{tabular}

As Table 1 revealed, majority of the respondents are female with a GWA in NS falling under 2.00-2.49; with regards to parent's highest educational attainment, the highest attainment is high school and the socio-economic status is middle income.

Table 2. Respondents' Ecological Awareness in Terms of Caring

\begin{tabular}{l|l|l|l}
\hline Item Statements & Mean & $\begin{array}{l}\text { Standard } \\
\text { Deviation }\end{array}$ & $\begin{array}{l}\text { Verbal } \\
\text { Interpretation }\end{array}$ \\
\hline $\begin{array}{l}\text { As an Education student, I ... } \\
\text { 1. reduce the negative impact I make in the environment by } \\
\text { following rules and regulations in my community. }\end{array}$ & 3.41 & 0.56 & Agree \\
\hline $\begin{array}{l}2 . \quad \text { consider teaching others important for them to know how to } \\
\text { take care of the environment. }\end{array}$ & 3.47 & 0.64 & Agree \\
\hline 3. approach people who litter in public places calmly. & 3.11 & 0.74 & Agree \\
\hline $4 . \quad$ avoid wasting resources such as food, water, energy and etc. & 3.59 & 0.61 & Strongly Agree \\
\hline $5 . \quad$ take good care of the plants and manage to make it grow. & 3.38 & 0.69 & Agree \\
\hline
\end{tabular}


6. refrain from burning wastes especially plastics to avoid pollution.

7. believe that environment awareness must be emphasized in schools as early as possible.

8. reduce the use of plastic by bringing eco bag when I go to the market.

9. support advocacies and campaigns which aim to take care of the environment.

10. promote care for the environment by being a volunteer.

Overall

\begin{tabular}{|l|l|l}
\hline 3.50 & 0.64 & Agree \\
\hline 3.78 & 0.43 & Strongly Agree \\
\hline 3.50 & 0.71 & Agree \\
\hline 3.47 & 0.69 & Agree \\
\hline 3.62 & 0.59 & Strongly Agree \\
$\mathbf{3 . 4 8}$ & $\mathbf{0 . 6 3}$ & Aware \\
\hline
\end{tabular}

Table 2 shows that the respondents were ecologically aware (3.48) with regards to caring. This implies that students are conscious on how to take good care of the environment. In the study of Anijaobi-Idem (2015), they suggested that adequate measures should be put in place where environmental awareness is sustained in the secondary schools in Calabar metropolis. This does not only increase the principal and teacher's awareness about environmental issues, but also to sensitize the students on this matter.

Table 3. Respondents' Ecological Awareness in Terms of Practical Competency

\begin{tabular}{l|l|l|l}
\hline Item Statements & Mean & $\begin{array}{l}\text { Standard } \\
\text { Deviation }\end{array}$ & $\begin{array}{l}\text { Verbal } \\
\text { Interpretation }\end{array}$ \\
\hline $\begin{array}{l}\text { As an Education student, I ... } \\
\begin{array}{l}\text { join in organizations that works on environmental } \\
\text { concerns. }\end{array}\end{array}$ & 2.75 & 0.68 & Sometimes \\
\hline $\begin{array}{l}2 . \quad \text { carry with me things that can be recycled until I find a } \\
\text { recycling bin. }\end{array}$ & 2.88 & 0.74 & Slightly Agree \\
\hline 3. separate recyclable items from items that go to the landfill. & 3.16 & 0.69 & Slightly Agree \\
\hline $4 . \quad$ join cleanliness campaign in school or community. & 3.05 & 0.62 & Slightly Agree \\
\hline $5 . \quad$ turn off the light when I leave a room. & 3.74 & 0.48 & Agree \\
\hline $6 . \quad$ turn off the faucet when not in use. & 3.80 & 0.46 & Agree \\
\hline $7 . \quad$ consume reusable water bottle and coffee cup. & 3.32 & 0.66 & Slightly Agree \\
\hline $\begin{array}{l}8 . \quad \text { make sure that I am informed about local, state, national, } \\
\text { or global issues related to the environment by watching the news } \\
\text { and surfing the internet. }\end{array}$ & 3.18 & 0.65 & Slightly Agree \\
\hline $\begin{array}{l}9 . \quad \text { advocate water conservation to save our planet Earth. } \\
\text { 10. ensure that my environment is clean by not littering. }\end{array}$ & 3.33 & 0.65 & Slightly Agree \\
\hline Overall & $\mathbf{3 . 2 7}$ & $\mathbf{0 . 6 2}$ & Alightly Agree \\
\hline
\end{tabular}

It can be seen from the table that the respondents were aware on practical competency (3.27). This signifies that they are mindful of the value of active involvement in activities and programs concerning the environment. This is justified by Verma (2016), which pointed out that youth continues to be involved in implementing environmental projects, and the experience they have gained qualifies them for increased participation in decision-making about environmental policies.

Table 5. Relationship between the Respondents' Profile and their Assessed Ecological Awareness

\begin{tabular}{|c|c|c|c|c|}
\hline Variables & $\begin{array}{l}\text { Computed } \\
\chi^{2}\end{array}$ & p Value & $\begin{array}{l}\text { Decision } \\
\left(\mathbf{H}_{0}\right)\end{array}$ & Interpretation \\
\hline $\begin{array}{l}\text { Sex and Ecological Awareness } \\
\text { Socio-economic Status and Ecological } \\
\text { Awareness }\end{array}$ & $\begin{array}{l}4.064 \\
15.158\end{array}$ & $\begin{array}{l}0.255 \\
0.019\end{array}$ & $\begin{array}{l}\text { Accept } \\
\text { Reject }\end{array}$ & $\begin{array}{l}\text { Not Significant } \\
\text { Significant }\end{array}$ \\
\hline $\begin{array}{l}\text { Parent's Highest Educational Attainment and } \\
\text { Ecological Awareness }\end{array}$ & 25.596 & 0.002 & Reject & Significant \\
\hline $\begin{array}{l}\text { GWA in Natural Science and Ecological } \\
\text { Awareness }\end{array}$ & 40.586 & 0.000 & Reject & Significant \\
\hline
\end{tabular}


The table revealed that there is no significant relationship between sex and ecological awareness while there is a significant relationship between socio-economic status, parent's highest educational attainment, GWA in NS and ecological awareness. This implies that students' sex has no bearing on their awareness on ecology. It is worth noting that all students are cognizant of their role on environmental conservation and preservation.

Table 6. Suggested Enrichment Activities to Strengthen Ecological Awareness among the Filipino Education Students

\begin{tabular}{|c|c|c|c|c|c|}
\hline Areas of Concern & Objectives & Strategies/ Activities & Person/s Involved & $\begin{array}{l}\text { Target } \\
\text { Date }\end{array}$ & $\begin{array}{l}\text { Expected Outcome/ } \\
\text { Output }\end{array}$ \\
\hline Caring & $\begin{array}{l}\text { To inculcate } \\
\text { care/concern for the } \\
\text { environment among } \\
\text { students }\end{array}$ & $\begin{array}{l}\text { Engagement to volunteer } \\
\text { works that promote care for } \\
\text { the environment can entail } \\
\text { progress and awareness to the } \\
\text { environment where we live } \\
\text { in. }\end{array}$ & $\begin{array}{lr}\text { Community, } & \text { Associate } \\
\text { Dean, Head } & \text { and } \\
\text { Coordinators of Extension } & \\
\text { Services, } & \text { Faculty } \\
\text { Members, } & \text { Education } \\
\text { Students, } & \text { Student } \\
\text { Organizations } & \\
\end{array}$ & September 2017 & $\begin{array}{l}\text { Filipino education } \\
\text { students are able to } \\
\text { connect and become } \\
\text { passionate to take care } \\
\text { of the environment. }\end{array}$ \\
\hline $\begin{array}{l}\text { Practical } \\
\text { Competency }\end{array}$ & $\begin{array}{l}\text { To strengthen students' } \\
\text { involvement in } \\
\text { conserving the } \\
\text { environment }\end{array}$ & $\begin{array}{l}\text { Active involvement to } \\
\text { organizations and campaigns } \\
\text { that work on environmental } \\
\text { concerns can be an initial step } \\
\text { towards change and } \\
\text { sustainability. }\end{array}$ & $\begin{array}{lr}\text { Community, } & \text { Associate } \\
\text { Dean, Head } & \text { and } \\
\text { Coordinators of Extension } & \\
\text { Services, } & \text { Faculty } \\
\text { Members, } & \text { Education } \\
\text { Students, } & \text { Student } \\
\text { Organizations } & \\
\end{array}$ & October 2017 & $\begin{array}{l}\text { Filipino education } \\
\text { students are highly } \\
\text { aware and responsible } \\
\text { to take an action } \\
\text { towards sustainability. }\end{array}$ \\
\hline $\begin{array}{l}\text { Ecological } \\
\text { Concepts and issues }\end{array}$ & $\begin{array}{l}\text { To strengthen students' } \\
\text { awareness on } \\
\text { environmental } \\
\text { concepts and issues. }\end{array}$ & $\begin{array}{l}\text { Attending to symposiums and } \\
\text { seminars regarding } \\
\text { environment-related matters } \\
\text { which can increase persons' } \\
\text { knowledge and } \\
\text { understanding about } \\
\text { ecological balance and } \\
\text { processes. }\end{array}$ & $\begin{array}{lr}\text { Community, } & \text { Associate } \\
\text { Dean, Head } & \text { and } \\
\text { Coordinators of Extension } \\
\text { Services, } & \text { Faculty } \\
\text { Members, } & \text { Education } \\
\text { Students, } & \text { Student } \\
\text { Organizations } & \end{array}$ & December 2017 & $\begin{array}{l}\text { Filipino education } \\
\text { students are } \\
\text { knowledgeable and } \\
\text { can understand } \\
\text { ecological concepts. }\end{array}$ \\
\hline
\end{tabular}

Table 6 shows the suggested enrichment activities together with its objectives and expected outcomes. The strategies enumerated were believed to strengthen the ecological awareness among the Filipino education students.

\section{Conclusions and Recommendations}

Majority of the respondents were female with a GWA in NS falling under 2.00-2.49; with regards to parent's highest educational attainment, the highest attainment was high school and the socio-economic status was middle income. It was also concluded that the respondents were ecologically aware in terms of caring and practical competency. Moreover, there is no significant relationship between sex and ecological awareness while there is a significant relationship between socio-economic status, parent's highest educational attainment, GWA in NS and ecological awareness.

The findings of the study afforded the researchers in drawing various suggested activities which may strengthen the ecological awareness of Filipino education students at BatStateU JPLPC - Malvar. The campus may provide and conduct activities such as clean-up drives for students to be reminded about the importance of not littering in maintaining the cleanliness of the environment. On the other hand, college educators may present video clips and documentaries showing the alarming environmental issues that the world's facing today to give awareness which may encourage the students to join in organizations that work on environmental concerns. The activities suggested may be considered by the concerned authorities for maximum implementation and actualization. Lastly, a followup study may be conducted considering other variables.

\section{References}

Akan, U. (2014). The Influence of Parents' Educational Background and Study Facilities on Academic Performance among Secondary School Students. Academia, 1, 7-8. Retrieved from https://www.Academia.Edu/7678232/The_Influence_Of_Parents_Educational_Backgroundandstudy_Facilit 
ies_On_Academic_Performance_Among_Secondaryschoolstudents

Anijaobi-Idem, F. N., Ukata, B. N., \& Bisong, N. N. (2015). Environmental Awareness and School Sanitation in Calabar Metropolis of Cross Rivers State, Nigeria. Journal of Education and Practice, 6(4). Retrieved from https://files.eric.ed.gov/fulltext/EJ1083753.pdf

Asmal, K. (2000). Norms and Standards for Educators. Government Gazette, 82. Retrieved from http://www.up2speed.co.za/Legislation/NORMS\%20AND\%20STANDARDS\%20FOR\%20

Balgopal, M. M., Wallace, A. M. (2009). Decisions and Dilemmas: Using Writing to Learn Activities to Increase Ecological Literacy. Journal of Environmental Education, 40(3), 13-26. https://doi.org/10.3200/JOEE.40.3.13-26

Borden, D. S. (2007). Collegiate ecological literacy requirements: A case study of Western State College of Colorado. Research Gate, pp. 2-53. Retrieved from https://www.researchgate.net/publication/36710480_Collegiate_ecological_literacy_requirements_A_case_ study_of_Western_State_College_of_Colorado

Bruyere, B. L. (2008). The Effects of Environmental Education on Ecological Literacy of First Year College Students. Journal of Natural Resources \& Life Sciences Education, 37, 20-26.

Buctot, B., Obrando, M., \& Silverino, L. (2012). Level of Awareness on Ecological Problems of Second Year Students at Lumbang National High School. (Unpublished Thesis) BatStateU JPLPC-Malvar Campus, Malvar, Batangas.

Burchett, J. H. (2015). Environmental Literacy and its Implications for Effective Public Policy Formation. Baker Scholar Projects, pp. 35. Retrieved from http://trace.tennessee.edu/utk_bakerschol/27

Chand, S. (2016). Incentives Types: Financial and Non-Financial Incentives Explained. Your Article Library. Retrieved from http://www.yourarticlelibrary.com/hrm/incentives/incentives

Datinguinoo, M., Delos Reyes, R., \& Godoy, R. (2007). Environmental Practices of Grade VI Pupils Banaba East Elementary School. (Unpublished Thesis) BatStateU Main Campus, Batangas City.

Davidson, M. F. (2010). Ecological Literacy Evaluation of the University of Iceland Faculty, Students, and Staff; Implications for a University Sustainability Policy. (Master's Thesis) Department of Earth Sciences, $\begin{array}{lllll}\text { University of } & \text { Iceland, } & \text { pp. } & \text { Retrieved } & \text { from }\end{array}$ http://citeseerx.ist.psu.edu/viewdoc/download?doi=10.1.1.831.1518\&rep=rep1\&type=pdf

DeK

ay, M. (n.d.). Systems Thinking as the Basis for an Ecological Design Education. Systems Ecodesign, pp. 1. Retrieved from http://web.utk.edu/ arch/Research_Outreach/scholarship/dekay/pdf/Systems_Thinking.pdf

Ecological Literacy (2016, May). Draft Global Issues Pilot. Retrieved from https://www.slideshare.net/enriccalvet/ecological-literacy Educational Review, 66, 377-397. https://doi:org/10.1080/00131911.2013.780009 EDUCATORS.pdf

Fababaer, K. G. F., et al. (2013). Level of Awareness and Participation in the Environmental Code Program of Grade VI Pupils at Alangilan Central School. (Unpublished Thesis) BatStateU JPLPC-Malvar Campus, Malvar, Batangas.

Finnie, R., \& Mueller, R. E. (2008). The Effects of Family Income, Parental Education and Other Background Factors on Access to Post-Secondary Education in Canada. Canadian Education Project. https://doi.org/10.2139/ssrn.2256114

Guerrero, L. I., \& Jordan, M. A. (2007). Environmental Awareness and Involvement of Students at Mabini High School. (Unpublished Thesis) BatStateU JPLPC-Malvar Campus, Malvar, Batangas.

Gutierrez, J. A. (2012). Ecological Concerns and Environmental Education Issues: Bases for Curricular and CoCurricular Initiatives. (Unpublished Thesis) BatStateU Main Campus, Batangas City.

Hanemann, U. (2015). Transforming Our World Literacy for Sustainable Development. UNESCO Institute for Lifelong Learning, pp. 4. Retrieved from https://files.eric.ed.gov/fulltext/ED564012.pdf

Henriques, G. (2013). What is Knowledge? A Brief Primer: A basic review of how Philosophers Approach Knowledge. Psychology Today. Retrieved from https://www.ncbi.nlm.nih.gov/pmc/articles/PMC2248287/

Ilao, C. M., et al. (2010). Global Warming: Threat to Human life. (Unpublished Thesis) BatStateU Main Campus, Batangas City. 
Lebo, III, N. F. (2012). Toward Ecological Literacy: A Permaculture Approach to Junior Secondary Science. Australian Journal of Environmental Education, 29(2), 241-242. https://doi.org/10.1017/aee.2014.9

McBride, B. B. (2011). Essential Elements of Ecological Literacy and the Pathways to Achieve It: Perspectives of Ecologists. Theses, Dissertations, \& Professional Papers. 380. Retrieved from https://scholarworks.umt.edu/etd/380

McGinn, A. E. (2014). Quantifying and Understanding Ecological Literacy: A Study of First Year Students at Liberal Arts Institutions. Dickinson College Honors Theses, paper 169. Retrieved from https://scholar.dickinson.edu/student_honors/169

Mohammed, K. H., Atagana, H. I., \& Edawoke, Y. (2014). The Difference between Male and Female Students' Self-Efficacy, Academic Engagement and Academic Achievement in Biology among Grade Ten Students in South Wollo Zone Schools in Ethiopia. Mediterranean Journal of Social Sciences, 5(23), 804-813. https://doi.org/10.5901/mjss.2014.v5n23p804

Nordquist, R. (2017, October 07). Defining Literacy Meaning and Importance Evolve Over Time. Retrieved from https://www.thoughtco.com/what-isliteracy-1691249

Republic Act No. 9512/ The LAWPHiL Project Arellano Law Foundation. (n.d.). Retrieved from https://www.lawphil.net/statutes/repacts/ra2008/ra_9512_2008.html

Reyes, J. A. L. (2014). Environmental Attitudes and Behaviors in the Philippines. Journal of Educational and Social Research, 4(6). https://doi.org/10.5901/jesr.2014.v4n6p87

Roy, P. (2016). A comparative study on Environmental Awareness between Primary and Secondary School Teachers. International Journal of Research in Economics and Social Sciences (IJRESS), 6(12), 255-259. Retrieved from http://euroasiapub.org/wp-content/uploads/2017/01/24ESSDec-4419-1.pdf

Stanger, N. R. G. (2007). Youth and Environmental Art: The Effects of the Island School on Ecological Literacy. Academia.edu, pp. ii.

Sterling, E. P. (2015). A Shifting Paradigm: Teachers' Beliefs and Methods For Fostering Ecological Literacy in Two Public Charter Schools. University of Alaska Scholar Works, pp. 2. Retrieved from https://scholarworks.alaska.edu/xmlui/bitstream/handle/11122/5760/Sterling_uaf_0006N_10313.pdf?sequen $\mathrm{ce}=1$ typesfinancial-andnon-financialincentives explained $/ 35360 /$

Verma, P. (2016). Youth Participation in Environment Protection. World Pulse. Retrieved from https://www.worldpulse.com/en/community/users/priya-verma/posts/65057

Weiner, S. J., \& Auster, S. (2007). From Empathy to Caring: Defining the Ideal Approach to a Healing Relationship. Yale Journal of Biology and Medicine, 80(3), 123-130.

Wilder, S. (2013). Effects of Parental Involvement on Academic Achievement: A Metasynthesis.

\section{Copyrights}

Copyright for this article is retained by the author(s), with first publication rights granted to the journal.

This is an open-access article distributed under the terms and conditions of the Creative Commons Attribution license (http://creativecommons.org/licenses/by/4.0/). 